\title{
The Impact of the Exchange Rate Regime on Exports: Evidence from the European Monetary System
}

\author{
Stilianos Fountas \\ University of Macedonia \\ Kyriacos Aristotelous \\ Otterbein College
}

\begin{abstract}
We employ the econometric techniques of multivariate cointegration and errorcorrection models to investigate the impact of the creation of the European Monetary System (EMS) on the volume of intra-European Union (EU) exports for eight EU countries. We find that for Ireland the EMS boosted the volume of intraEU exports, whereas for Belgium, Denmark, and Germany, the EMS led to a decline in intra-EU exports. In the rest of the countries, there has not been a significant effect. Another important result is that, more often than not, the shortrun impact of exchange rate volatility on the volume of intra-EU exports is insignificant.
\end{abstract}

- JEL Classifications: F14, F33

- Key words: Exchange rate regime, Exchange Rate Volatility, Exports, European monetary system

\section{Introduction}

The volume of research focusing on the determinants of export demand in

\footnotetext{
*Corresponding address: Stilianos Fountas, Department of Economics, University of Macedonia, 156 Egnatia St. 54006 Thessaloniki, Greece, Tel: +30-2310-891774, Fax: +30-2310-891292, E-mail: sfountas @uom.gr. Kyriacos Aristotelous, Department of Business, Accounting and Economics, Otterbein College. One Otterbein, Westerville, OH 43081, USA, Tel: +1-614-823-1611, Fax: +1-614-823-1014, Email: Karistotelous@otterbein.edu @2005-Center for International Economics, Sejong Institution, All Rights Reserved.
} 
industrial and developing countries, alike, has grown significantly in recent years. The increasing interest in the topic has been sparked by developments in the econometrics of nonstationary macroeconomic time series and the theoretical ambiguity that surrounds the relationship between exports and exchange rate uncertainty. An important issue that has been left out of the discussions, however, is the impact of the exchange rate regime on the volume of trade ${ }^{1}$. This study attempts to close, at least partially, the gap in the existing literature by investigating the impact of the creation of the Exchange Rate Mechanism (ERM) associated with the launch of the European Monetary System (EMS) in March 1979 on the volume of trade between European Union (EU) member countries.

Following the launch of the last stage of the Economic and Monetary Union (EMU) on January 1, 1999, the relationship between the exchange rate regime and the volume of exports within the EU acquires increasing importance since the EUmember countries proceeded to lock their currencies in a system of irrevocably fixed exchange rates and eventually a single currency. Evidence in favour of a positive association between exchange rate stability obtained by the ERM and export volume would provide an indication of potentially additional benefits in terms of output growth in the EU (the export-led growth hypothesis) and, thus, give additional ammunition to the proponents of EMU.

The launch of the EMS, a system of fixed, yet adjustable, exchange rates would be expected to affect intra-EU trade in a number of ways. First, the lower nominal and real exchange rate uncertainty resulting from the ERM ${ }^{2}$ would be expected to have a direct impact on the volume of intra-EU exports and imports. According to the existing theoretical literature, this direct impact might be positive or negative depending on whether we allow for risk-averse traders. Second, the reduction in exchange rate uncertainty brought by the ERM would lead to higher output as interest rates would tend to converge to a lower average level, and, hence, have an indirect impact on export growth. According to De Grauwe (2000), lower exchange rate uncertainty associated with a smaller exchange rate variability would increase the quality of information provided by the price mechanism of resource

\footnotetext{
${ }^{1}$ In the last few years, a number of papers (Frankel and Rose, 2002; Rose, 2000, 2001; Rose and van Wincoop, 2001, Glick and Rose, 2002) have addressed the issue of the impact of a currency union on trade flows. However, this literature offers only predictions regarding the likely impact of EMU on intraEU trade.
}

${ }^{2}$ Gros and Thygesen (1998) report evidence of a lower nominal and real exchange rate uncertainty in intra-ERM exchange rates following the creation of the EMS. 
allocation. The fall in risk would reduce the risk premium incorporated in the expected return on investment projects and, hence, the real interest rate, thus, boosting output growth. The result of output growth would be an increase in the demand for exports in foreign countries.

Changes in exchange rate uncertainty related to the ERM represent one of the factors accounting for the change in the volume of intra-EU trade in recent years. An additional factor is the application of contractionary monetary and fiscal policies in most member countries in preparation for their participation in the EMU, as required under the Maastricht Treaty convergence criteria. These policies would be expected to lead to a reduction in the volume of intra-EU trade due to negative output effects.

A further effect of the EMS on intra-EU exports would be the anticipation that the launch of the European monetary integration process would lead to further real integration as the monetary and real integration processes are considered to be complementary. In other words, the EMS would lead to increasing prospects for real integration and more inward foreign direct investment (FDI) in the EU, which in turn, will result in additional intra-EU trade (and export) flows ${ }^{3}$. A case in point is Ireland where foreign MNCs established a production base in order to export their goods to the rest of the EU. The positive impact of the anticipation of further real integration in the EU, as captured by the Single Market Act of 1986, on inward FDI has been shown in a study by Aristotelous and Fountas (1996).

However, it is also possible that the creation of the EMS created prospects of monetary contraction in the then EC as several member countries were required to follow the tight monetary policies implemented by Germany. In addition, the widening of the exchange rate bands in 1993 happened at a time member countries implemented restrictive fiscal policies necessitated by the Maastricht criteria. These prospects of a slowdown in EU income growth rates would be expected to have a contractionary effect on inward FDI in the EU and hence intra-EU exports.

In light of the above discussion, the effect of a change in the exchange rate regime (the creation of the EMS) in the EU on intra-EU trade is, a priori, ambiguous. An empirical investigation is, therefore, needed to resolve this ambiguity. To this end, we make use of a relatively recent approach to model the determinants of export volume. In this paper, we specifically look at eight EU countries, namely, Belgium,

\footnotetext{
${ }^{3}$ More monetary integration would also enhance the prospects of further reduction in exchange rate uncertainty in the EU and hence would also contribute to attracting foreign MNCs and increasing intraEU exports.
} 
Denmark, France, Germany, Ireland, Italy, the Netherlands and UK.

Our econometric methodology is in line with the recent literature that has applied developments in the econometrics of nonstationary time series in order to estimate long run and short-run export functions. However, we deviate from this literature in a number of ways: First, we focus on member countries of the EU and analyse explicitly intra-EU trade flows. Our motivation derives from the special exchange rate arrangement that applied in these countries since the inception of the EMS. Second, we are especially interested in estimating the impact of the EMS on intra-EU exports in a framework that is general enough to account for several economic determinants of export volumes. To accomplish our objectives, for each country, we estimate an export function and test for the influence of the exchange rate regime on export volume. We are also interested in the impact of changes in exchange rate uncertainty on export volume, as our findings on this issue will allow us to project the impact of the launch of the single European currency on intra-EU exports.

The paper is organised as follows: Section II discusses the theoretical model and outlines the literature and section III outlines our econometric methodology. Section IV describes our data, summarises our results and provides an interpretation of these results. Finally, section V provides some policy implications and concludes.

\section{Theoretical Background and Literature}

The empirical literature on the estimation of export functions uses the following long-run export function (see, e.g., Chowdhury, 1993, and Arize, 1995):

$$
\ln X_{t}=\beta_{0}+\beta_{1} \ln Y_{t}+\beta_{2} \ln P_{t}+\beta_{3} V_{t}+\beta_{4} D_{1 t}+\beta_{5} D_{2 t}+u_{t}
$$

where $X_{t}$ stands for real exports, $Y_{t}$ for real foreign income, $P_{t}$ for relative prices (a measure of competitiveness), $V_{t}$ for exchange rate uncertainty, and ut is the error term. We have added two dummy variables $D_{1}$ and $D_{2}$ (defined below) to the above equation to capture the impact of the exchange rate regime on exports.

Gotur (1985) shows that equation (1), excluding the uncertainty and dummy variables, is the long-run solution to a system of behavioural demand and supply functions for exports. Economic theory suggests that the impact of real foreign income on real exports should be positive and the impact of relative price on real exports negative. Traditional trade theory suggests that exchange rate uncertainty would depress trade because exporters would view it as an increase in the 
uncertainty of profits on international transactions, under the assumption of risk aversion. On the other hand, a number of authors such as De Grauwe $(1988,2000)$, Giovannini (1988), Franke (1991), Sereu and Vanhulle (1992) and Viaene and de Vries (1992) illustrate, in the context of theoretical models, that exchange rate uncertainty might benefit trade. Hence, the sign of b3 in equation (1) is ambiguous from a theoretical point of view.

This, a priori, surprising theoretical result has a simple interpretation. De Grauwe (2000) shows that if the response of exports to the exchange rate is positive (i.e., a domestic currency depreciation increases exports), then firms profits will be convex in the exchange rate. This implies that a higher variability in the exchange rate will raise expected profits. Hence, risk neutral firms will respond to higher exchange rate variability by increasing their exports. If firms are risk averse, the positive relationship between variability and exports may still hold, provided that the increase in firm utility from increased average profits more than offsets the decline in utility from greater uncertainty of profits.

The international empirical evidence on the influence of uncertainty on exports is also mixed. IMF (1984), Cote (1994) and McKenzie (1999) provide comprehensive reviews of the empirical literature. Most of the studies in the literature use US dollar exchange rates and, hence, are not directly related to our study that concentrates on ERM exchange rates and intra-EU trade. There are, however, a few exceptions, e.g., De Grauwe (1987), Bini-Smaghi (1991) and Stokman (1995). De Grauwe (1987) and Bini-Smaghi (1991) consider aggregate intra-EMS trade and find evidence that the greater exchange rate stability achieved by the ERM has had a positive effect on intra-ERM trade. Stokman (1995) focuses on the relationship between exchange rate uncertainty and the volume of intra-EU trade at the sectoral level. He finds that exchange rate uncertainty is negatively and highly significantly related to intra-EU trade in 90 per cent of all cases examined. These three studies do not perform stationarity tests and, hence, the common finding of a negative and significant relation between uncertainty and trade might be spurious. Moreover, these studies do not consider the effect of the exchange rate regime on intra-EU exports, but only the relationship between exports and uncertainty. However, as mentioned in our introduction, and as further explained below, exchange rate stability obtained by the ERM represents one of the several factors explaining the recent change in the volume of intra-EU trade. A recent study by Fountas and Aristotelous (1999) attempts to address the issue of the impact of the ERM on intra-EU trade. The authors consider the four largest EU countries only 
(France, Germany, Italy and UK) and examine whether the anticipation of more real integration and contractionary monetary policies created by the launch of the EMS has had any impact on intra-EU exports. The authors find no evidence for such an impact. By focusing only on the four largest EU countries, a complete assessment of the EMS impact on intra-EU trade cannot be carried out since the full effect of the exchange rate regime on exports cannot be captured. Given this preliminary nature of the results of the Fountas and Aristotelous (1999) study, the present paper considers all eight EU countries that were ERM-members at its launch.

The early literature that investigated the impact of the exchange rate regime on trade flows, to the best of our knowledge, includes only Brada and Mendez (1988) and Pozo (1992). None of these studies looked at the EMS. Recently, there has been a growing literature that examines the effect of the exchange rate regime on trade that includes Rose (2000, 2001), Rose and van Wincoop (2001), Frankel and Rose (2002) and Glick and Rose (2002). The primary objective of these papers is to investigate the effect of currency unions on trade flows using data on a large number of countries. The main finding of the literature is that the creation of a currency union at least triples the volume of trade among the member countries. This result seems to be quite robust and is based on large data sets that include existing currency unions and data extending to the 1990s. The fast growing literature on the effects of currency unions on trade is summarised in Rose (2004). Using quantitative techniques for the evaluation and combination of empirical results from different studies, Rose (2004) concludes that currency unions do affect significantly trade flows.

The EMU is however not included in most of the existing studies. Nevertheless, Rose and van Wincoop (2001) use pre-EMU data on EMU countries to forecast the level of intra-EMU trade following the launch of the Euro. They estimate that EMU will raise European trade by over 50 per cent. The more recent studies by Micco et al. (2003) and de Nardis and Vicarelli (2003) include data from the Euro zone in their study of the effect of currency unions on trade. Micco et al. (2003) use panel data for the 1992-2002 period for 22 developed countries, including the twelve Euro-zone member countries. Making use of different samples and methodologies, the authors find the positive effect of the introduction of the Euro on intra-EU trade is between 4 and 16 per cent. Moreover, there is evidence that EMU, rather than diverting trade away from non-member countries, it has actually boosted trade with non-member countries as well. De Nardis and Vicarelli (2003) 
using a gravity model find that the Euro introduction led to an increase in bilateral intra-EU trade by about 9-10per cent. Overall, the recent evidence shows that the Euro has had a positive impact on intra-EU trade; however, this impact has been much smaller than that obtained in other currency unions.

In this paper $\mathrm{D}_{1}$ takes the value of one when the exporting country was an ERM member at its initial stage when the narrow band of \pm 2.25 per cent was in force. $\mathrm{D}_{2}$ takes the value of one when the exporting country was an ERM member following the widening of the bands to \pm 15 per cent in August 1993 (August 1993December 1996). These dummies capture factors that account for the impact of the exchange rate regime on intra-EU exports other than those that work through changes in income, relative prices, and exchange rate uncertainty ${ }^{4}$. For $\mathrm{D}_{1}$, these factors include the anticipation of further real integration (whose effect on exports is expected to be positive) and the anticipation about contractionary monetary policies (whose influence on exports is expected to be negative). $\mathrm{D}_{2}$ first captures the anticipation of more real integration. It also captures the market's anticipation about restrictive fiscal policies, as these policies were required under the Maastricht criteria in preparation for their participation in the last stage of EMU, and therefore, reduced prospects for the viability of inward FDI and export supply. Hence, the sign of $\mathrm{D}_{2}$ is ambiguous.

\section{Econometric Methodology}

Most of the previous empirical research on the estimation of export functions used classical regression analysis and did not examine the integration properties of the relevant time series. These studies can be criticized along the following lines. First, the conventional statistical tests employed are inappropriate if the individual series are non-stationary as the OLS estimators are not consistent and the standard $t$ and F statistics do not follow the Student's t and F distributions. Second, even if the non-stationary series are cointegrated, classical statistical inference is invalid since the estimated standard errors are inconsistent (Stock, 1987).

In agreement with developments in the econometrics of non-stationary time

\footnotetext{
${ }^{4}$ Notice that the effects of changes in exchange rate uncertainty (both direct and indirect, as mentioned in the introduction), income (due to contractionary fiscal and monetary policies), and relative prices (for example, the real appreciation of the Irish punt and the Italian lira) on exports are reflected in the values of the three independent variables of equation (1) and cannot be captured by the dummy variables. However, the anticipation of further real integration and contractionary policies is captured by the dummy variables.
} 
series, we start by estimating a long-run relationship between exports and its determinants implied by equation (1). We have decided to use the Johansen multivariate cointegration approach. Our choice is justified by Phillips (1991) who finds that the Johansen approach is optimal in terms of symmetry, unbiasedness and efficiency. A Monte Carlo study by Gonzalo (1994) supports the superior properties of the Johansen technique relative to several other single and multivariate techniques. In the Johansen framework, all variables, including exchange rate uncertainty, are treated as endogenous. The ERM dummy variables are the only exogenous variables. The treatment of uncertainty as an endogenous variable is particularly important in the context of the EU where Central Banks have tried systematically to stabilize the nominal exchange rates against the DM and hence against the currencies of the other ERM-member countries.

According to the Granger representation theorem (Engle and Granger, 1987), if the variables in equation (1) are cointegrated, then it can be shown that the errorcorrection model (ECM) for exports will be of the following form:

$$
\begin{aligned}
\Delta \ln X_{t}= & \alpha_{0}+\alpha_{1} R_{t-1}+\alpha_{2} D_{1 t}+\alpha_{3} D_{2 t}+\sum_{i=1}^{n} \gamma_{i} \Delta \ln X_{t-i}+\sum_{i=1}^{n} \delta_{i} \Delta \ln X_{t-i}+ \\
& \sum_{i=1}^{n} \varepsilon_{i} \Delta \ln P_{t-i}+\sum_{i=1}^{n} \zeta_{i} \Delta V_{t-i}+e_{t}
\end{aligned}
$$

where $\Delta$ is the first-difference operator, $\mathrm{R}_{\mathrm{t}-1}$ is the error-correction term (ECT), i.e., the one-period lagged error term in the cointegrating regression, $D_{l t}$ is a dummy variable that takes the value one when the exporting country was a member of the narrow-band ERM and zero otherwise, $D_{2 t}$ is a dummy variable that takes the value one when the exporting country was a member of the wide-band ERM and zero otherwise ${ }^{5}, X_{t}, Y_{t}, P_{t}$ and $V_{t}$ are as defined earlier, and et is an error term. The rest of the equations in the ECM (not given) are analogous to equation (2) with the only difference being in the left-hand side variable of the equation. This ECM allows us to estimate the short-run relationships between exports and its determinants. It includes both the short-run dynamics and the long-run relation

\footnotetext{
${ }^{5}$ The dummy variable $D_{l}$ takes the value one during the period 1979.II-1993.II for Belgium, Denmark, France, Germany, Ireland, and the Netherlands, and for the periods 1979.II-1992.III and 1990.IV-1992.III for Italy and the UK, respectively. The dummy variable $D_{2}$ takes the value one during the period 1993.III1996.IV for Belgium, Denmark, France, Germany, Ireland, and the Netherlands.
} 
between the series. The parameter a1 measures the response of real exports in each period to departures from the long-run equilibrium. With the cointegrating equation normalised on exports, a1 is expected to have a negative sign and be statistically significant.

\section{Data and Results}

\section{A. Data}

We use quarterly data for the period 1973-1996 and our sample includes eight EU countries, namely, Belgium, Denmark, France, Germany, Ireland, Italy, the Netherlands and UK. The beginning of the sample period coincides with the start of the floating exchange rate regime following the collapse of the Bretton-Woods system.

The export variable includes each country's exports to the other seven countries of our sample. Its real value is created through division by the unit export value. Our first explanatory variable in the export function is foreign income. For each country, this series is constructed by taking the weighted average of the industrial production indexes of the other seven countries. The choice of industrial production is due to the absence of quarterly GDP data in several countries in our sample. Each country's trade weights are calculated by determining the share of bilateral trade (exports and imports) in total trade between each country and its seven trading partners. The source of the export data is the OECD Monthly Statistics of Foreign Trade. The source of the rest of the series is the International Financial Statistics (IFS) published by the IMF.

The second right-hand side variable in equation (1) is a measure of competitiveness. It is defined as the ratio of the exchange rate-adjusted price of domestic country exports to the price of exports of the other seven countries. Hence, it is the ratio of the domestic unit export value to the weighted average of the unit export values of the other seven countries, denominated in the domestic currency. The weights are identical to those used in the construction of the income variable.

The measurement of exchange rate uncertainty represents a contentious issue in the empirical literature on the effects of exchange rate uncertainty on trade. To make sure our results are not influenced by the choice of our proxy, we have decided to use three different proxies for exchange rate uncertainty. First, we employ the moving standard deviation of the growth rate of the nominal effective 
exchange rate:

$$
V_{t}=\left[(1 / m) \sum_{i=1}^{m}\left(\ln Z_{t-1}-\ln Z_{t-2}\right)^{2}\right]^{1 / 2}
$$

where $\mathrm{Z}$ is the nominal effective exchange rate and $\mathrm{m}$, the order of the moving average, is set equal to $10^{6}$. The nominal effective exchange rate is calculated by the weighted average of the exchange rates where the trade weights are the ones used in creating foreign income and relative prices ${ }^{7}$. This measure of exchange rate uncertainty is adopted by several authors, including Lastrapes and Koray (1990) and Chowdhury (1993).

Second, we estimate an autoregressive regression for the exchange rate using the rolling regression method to obtain a time series of the standard errors of the regressions as a proxy for exchange rate uncertainty. Third, we use the GARCH approach to obtain the conditional variance of the exchange rate as a measure of the time-varying exchange rate uncertainty. Given our low-frequency data, we anticipate that in several cases, evidence for GARCH effects will not apply.

\section{B. Results}

We first employed Augmented Dickey Fuller (ADF) and Phillips-Perron unit root tests to determine the integration properties of each time series. The results of these tests, available upon request from the authors, imply that most series are I(1). Exceptions are the moving standard deviation measure of exchange rate uncertainty for the UK, the rolling regression measures for Belgium, Denmark, France, Germany, the Netherlands and the UK, and all GARCH measures of uncertainty that are $\mathrm{I}(0)$. Then, we proceeded to test for cointegration following the Johansen maximum likelihood approach among the variables in equation (1). We chose the lag length in the VAR using a likelihood ratio test. The results of the trace and maximum eigenvalue tests, also available upon request from the authors, illustrate that there exists a unique cointegrating vector for the majority of countries included in the study. For the remaining countries included in the study, the tests indicate that there exists either no cointegrating vector or more than one vector.

\footnotetext{
${ }^{6}$ Our main results turned out to be robust to alternative specifications of the order of the moving average.

${ }^{7}$ Although we use nominal exchange rates to calculate our volatility measure, Chowdhury (1993), Lastrapes and Koray (1990) and Thursby and Thursby (1987) obtain similar results using nominal and real exchange rates.
} 
Following the convention, in this latter group of countries, we have chosen the most significant vector, i.e., the one that corresponds to the largest eigenvalue, in the analysis that follows.

We do not report the estimated cointegrating vectors as our primary interest lies in the impact of the EMS on exports. Using the cointegration vectors normalized on exports, we estimated the ECMs for exports and report the results for each country in Tables 1-8. To decide the final forms of the ECMs, we started with the maximum lag suggested by the likelihood ratio test for each variable included in the VAR and eliminated insignificant lags unless this introduced serial correlation in the error term. This allowed us to derive a parsimonious model. Tables 1-8 report the short-run export functions using the three different measures of exchange rate uncertainty. For five countries in our sample, namely, Belgium, Denmark, Germany, the Netherlands, and the UK no evidence for GARCH effects was found.

Before we discuss the results, we need to determine the adequacy of the ECMs. For that reason, we performed a number of tests which are reported in the last column of each table. These tests indicate that the ECMs are adequate for further analysis. The adjusted $R 2$ ranges from a low 0.23 to a high 0.57 . Such values compare well with the adjusted $R 2$ values of other studies for regressions based on first differences in variables. The Breusch-Godfrey Serial Correlation LM test ( $F$ statistic) indicates that there is no serial correlation in the residuals of the estimated equations at the 5 per cent level. Moreover, autoregressive conditional heteroskedasticity (ARCH) does not seem to be a problem according to the ARCH LM test ( $F$-statistic).

Having provided evidence supporting the adequacy of the estimated ECMs, we can make a number of observations regarding the estimates presented in Tables 18. First, the ECM results show that changes in foreign income and relative prices have statistically significant short-run effects (in some cases at the 10 per cent level of significance) on exports. Second, the dynamics of the ECM equations indicate, more often than not, that the short-run impact of exchange rate volatility on the volume of intra-EU exports is insignificant. Specifically, in the case of Denmark, France, and Italy, the impact of exchange rate volatility on intra-EU exports is not statistically significant regardless of how volatility is measured. In the case of Germany and UK, the impact of exchange-rate volatility on intra-EU exports is negative and statistically significant. In the case of Belgium, Ireland, and the Netherlands the impact of exchange rate volatility on intra-EU exports is mixed. The net effect of volatility on trade, however, appears to be small in all three 
Table 1. Error-Correction Regression Results -BELGIUM

Dependent Variable: $\Delta \ln \mathrm{X}$

\begin{tabular}{lcc}
\hline & Model 1 & Model 2 \\
\hline Error Correction Term (-1) & $-0.08(1.64)$ & $-0.10(2.85)^{*}$ \\
$\Delta \ln \mathrm{X}(-1)$ & $-0.13(1.19)$ & $-0.15(1.66)^{* *}$ \\
$\Delta \ln \mathrm{X}(-2)$ & $-0.20(2.15)^{*}$ & $-0.11(1.17)$ \\
$\Delta \ln \mathrm{X}(-3)$ & $-0.17(1.91)^{* *}$ & $-0.11(1.26)$ \\
$\Delta \ln \mathrm{X}(-4)$ & $0.58(6.28)^{*}$ & $0.63(7.01)^{*}$ \\
$\Delta \ln \mathrm{X}(-5)$ & $-0.14(1.18)$ & \\
$\Delta \ln \mathrm{Y}(-1)$ & $2.25(2.49)^{*}$ & $1.29(1.40)$ \\
$\Delta \ln \mathrm{Y}(-2)$ & $0.84(0.91)$ & $1.11(1.19)$ \\
$\Delta \ln \mathrm{Y}(-3)$ & $1.21(1.36)$ & $2.00(2.17)^{*}$ \\
$\Delta \ln \mathrm{P}(-2)$ & $0.54(1.45)$ & $0.43(1.11)$ \\
$\Delta \ln \mathrm{P}(-3)$ & & $-0.76(2.02)^{*}$ \\
$\Delta \ln \mathrm{P}(-4)$ & $-0.83(2.32)^{*}$ & \\
$\Delta \ln \mathrm{P}(-5)$ & & $-0.70(1.86)^{* *}$
\end{tabular}

Moving Standard Deviation Measure of Vol.

$\Delta \mathrm{V}(-1)$

Rolling Regression Measure of Vol.

$\mathrm{V}(-3)$

$\mathrm{V}(-5)$

Dummy 1

$-0.01(0.56)$

$-0.08(2.38)^{*}$

Dummy 2

$-0.01(0.46)$

$-0.11(2.29)^{*}$

Adjusted R-squared

F-statistic

B-G Serial Correlation (F Test)

$1.50(0.21)$

$0.89(0.47)$

ARCH (F test)

$0.68(0.61)$

Notes: The figures in parentheses are the absolute t-statistics. * and ** denote significance at the 5 per cent and 10 per cent levels, respectively. F statistics are followed by marginal significance levels in parentheses.

countries. Our overall finding that the impact of volatility on intra-EU trade is insignificant does not provide support for Stockman's (1995) result that exchange rate uncertainty is negatively and highly significantly related to intra-EU trade in 90 percent of all cases examined. According to our theoretical literature, our finding of an insignificant effect of volatility on trade is not surprising. For example, under risk averse exporters, it is possible that the increase in exporters' utility from increased average profits is approximately offset by the decline in their utility due to more uncertainty about profits (de Grauwe, 2000). The likely outcome is that a 
Table 2. Error-Correction Regression Results - DENMARK

Dependent Variable: $\Delta \ln \mathrm{X}$

\begin{tabular}{lcc}
\hline & Model 1 & Model 2 \\
\hline Error Correction Term (-1) & $-0.09(2.90)^{*}$ & $-0.08(2.67)^{*}$ \\
$\Delta \ln \mathrm{X}(-4)$ & $0.53(5.86)^{*}$ & $0.52(6.08)$ \\
$\Delta \operatorname{lnY}(-1)$ & $0.81(1.07)$ & $0.65(0.85)$ \\
$\Delta \ln Y(-2)$ & & $0.54(0.76)$ \\
$\Delta \operatorname{lnY}(-5)$ & $1.11(1.61)$ & $0.68(1.06)$ \\
$\Delta \operatorname{lnP}(-1)$ & $-0.81(2.57)^{*}$ & $-0.78(2.60)^{*}$ \\
$\Delta \operatorname{lnP}(-2)$ & $0.35(1.14)$ & $0.44(1.51)$ \\
Moving Standard Deviation Measure of Vol. & & \\
$\Delta$ V(-3) & $-3.16(1.12)$ & \\
$\Delta$ V(-5) & $-3.43(1.21)$ & \\
Rolling Regression Measure of Vol. & & $-0.55(0.52)$ \\
V(-2) & & $0.69(0.59)$ \\
V(-5) & & $-0.11(2.70)^{*}$ \\
Dummy 1 & $-0.07(2.78)^{*}$ & $-0.11(2.53)^{*}$ \\
Dummy 2 & $-0.10(2.57)^{*}$ & 0.34 \\
Adjusted R-squared & 0.35 & $5.22(0.00)$ \\
F-statistic & $5.10(0.00)$ & $1.83(0.13)$ \\
B-G Serial Correlation (F Test) & $1.65(0.17)$ & $0.90(0.47)$ \\
ARCH (F test) & $1.57(0.19)$ &
\end{tabular}

Notes: The figures in parentheses are the absolute t-statistics. * and ** denote significance at the 5 per cent and 10 per cent levels, respectively. $\mathrm{F}$ statistics are followed by marginal significance levels in parentheses.

change in exchange rate volatility has no effect on trade.

The error-correction coefficients are correctly signed for all countries except Ireland. In some cases (model (1) for Belgium, Italy, and model (2) for the Netherlands), these coefficients are not significant. The positive sign of the errorcorrection coefficient for Ireland indicates that exports do not restore the long-run equilibrium. A possible explanation for this sign is that multinational corporations, which make up a large part of Irish exporters, are price setters and, therefore, the adjustment towards long-run equilibrium takes place through changes in relative prices and not export volumes. These results on the error-correction coefficients for these countries are still consistent with the finding of cointegration, since it is only sufficient that one of the error-correction coefficients in the system of the errorcorrection regressions for each country be negatively signed and statistically significant (Enders, 1995, p. 370).

Finally, and perhaps most importantly, the statistical significance of the EMS 
Table 3. Error-Correction Regression Results - FRANCE

Dependent Variable: $\Delta \ln \mathrm{X}$

\begin{tabular}{|c|c|c|c|}
\hline & Model 1 & Model 2 & Model 3 \\
\hline Error Correction Term (-1) & $-0.03(1.72)^{* *}$ & & $-0.21(4.45)^{*}$ \\
\hline$\Delta \ln X(-1)$ & $-0.22(2.60)^{*}$ & $-0.16(2.04)^{*}$ & $-0.07(1.01)$ \\
\hline$\Delta \ln X(-2)$ & $-0.16(1.86)^{* *}$ & & \\
\hline$\Delta \ln X(-3)$ & $-0.14(1.63)^{* *}$ & & \\
\hline$\Delta \ln X(-4)$ & $0.48(5.51)^{*}$ & $0.62(8.09)^{*}$ & $0.60(8.16)^{*}$ \\
\hline \multicolumn{4}{|l|}{$\Delta \ln X(-5)$} \\
\hline$\Delta \ln X(-6)$ & & $-0.12(2.43)^{*}$ & \\
\hline$\Delta \ln Y(-1)$ & $1.98(2.43)^{*}$ & $1.42(2.14)^{*}$ & \\
\hline \multicolumn{4}{|l|}{$\Delta \ln Y(-2)$} \\
\hline$\Delta \ln Y(-3)$ & & & $-0.66(0.98)$ \\
\hline$\Delta \ln \mathrm{P}(-1)$ & & & $-0.11(0.26)$ \\
\hline \multicolumn{4}{|l|}{$\Delta \ln \mathrm{P}(-2)$} \\
\hline$\Delta \ln P(-3)$ & $0.79(1.86)^{* *}$ & & \\
\hline$\Delta \ln \mathrm{P}(-4)$ & $0.94(2.22)^{*}$ & $0.41(1.05)$ & \\
\hline \multicolumn{4}{|c|}{ Moving Standard Deviation Measure of Vol. } \\
\hline$\Delta \mathrm{V}(-1)$ & $-3.03(0.98)$ & & \\
\hline \multicolumn{4}{|c|}{ Rolling Regression Measure of Vol. } \\
\hline $\mathrm{V}$ & & $-0.21(0.34)$ & \\
\hline \multicolumn{4}{|l|}{ GARCH Measure of Volatility } \\
\hline $\mathrm{V}$ & & & $-16.73(1.36)$ \\
\hline Dummy 1 & $0.03(1.48)$ & $0.01(0.31)$ & $-0.02(1.62)$ \\
\hline Dummy 2 & $-0.00(0.19)$ & $-0.01(0.49)$ & $-0.03(1.49)$ \\
\hline Adjusted R-squared & 0.52 & 0.52 & 0.57 \\
\hline F-statistic & $9.65(0.00)$ & $14.32(0.00)$ & $17.61(0.00)$ \\
\hline B-G Serial Correlation (F Test) & $0.71(0.59)$ & $0.34(0.85)$ & $0.39(0.82)$ \\
\hline $\mathrm{ARCH}(\mathrm{F}$ test $)$ & $1.57(0.19)$ & $1.64(0.17)$ & $0.80(0.53)$ \\
\hline
\end{tabular}

Notes: The figures in parentheses are the absolute t-statistics. ${ }^{*}$ and $* *$ denote significance at the 5 per cent and 10 per cent levels, respectively. F statistics are followed by marginal significance levels in parentheses.

dummy variables differs widely across the eight countries included in this study. In addition, in some countries, the impact of the EMS on exports seems to depend on the proxy used to measure exchange rate uncertainty. More specifically, our results indicate the following: First, the coefficients of both EMS dummy variables are positive and statistically significant only for Ireland. Second, the coefficients are

\footnotetext{
${ }^{8}$ For Germany the signs of the coefficients of the dummies seem to depend on the choice of the exchange rate uncertainty proxy. However, we can choose the "best" model of the two on the basis of the maximum value of the adjusted $R^{2}$.
} 
Table 4. Error-Correction Regression Results - GERMANY

Dependent Variable: $\Delta \ln \mathrm{X}$

\begin{tabular}{|c|c|c|}
\hline & Model 1 & Model 2 \\
\hline Error Correction Term (-1) & $-0.08(2.38)^{*}$ & $-0.00(3.01)^{*}$ \\
\hline$\Delta \ln X(-1)$ & & $-0.24(2.11)^{*}$ \\
\hline$\Delta \ln X(-2)$ & & $-0.26(3.07)^{*}$ \\
\hline$\Delta \ln X(-3)$ & $-0.21(2.21)^{*}$ & $-0.25(3.13)^{*}$ \\
\hline$\Delta \ln X(-4)$ & $0.40(3.99)^{*}$ & $0.39(3.43)^{*}$ \\
\hline$\Delta \ln X(-5)$ & $-0.31(3.33)^{*}$ & $-0.22(2.39)^{*}$ \\
\hline$\Delta \ln X(-6)$ & $-0.26(2.62)^{*}$ & \\
\hline$\Delta \ln Y(-1)$ & $1.38(1.75)^{* *}$ & $1.66(4.04)^{*}$ \\
\hline$\Delta \ln Y(-2)$ & & \\
\hline$\Delta \ln Y(-3)$ & & $1.11(1.88)^{* *}$ \\
\hline$\Delta \ln Y(-4)$ & & \\
\hline$\Delta \ln P(-1)$ & $-0.31(1.06)$ & $0.30(1.07)$ \\
\hline$\Delta \ln \mathrm{P}(-2)$ & & $0.72(1.64)^{* *}$ \\
\hline$\Delta \ln \mathrm{P}(-3)$ & & \\
\hline$\Delta \ln \mathrm{P}(-4)$ & & \\
\hline$\Delta \ln \mathrm{P}(-5)$ & & $0.47(2.18)^{*}$ \\
\hline $\begin{array}{l}\text { Moving Standard Deviation Me } \\
\Delta \mathrm{V}(-1) \\
\Delta \mathrm{V}(-2)\end{array}$ & & \\
\hline$\Delta \mathrm{V}(-3)$ & $-4.51(2.63)^{*}$ & \\
\hline $\begin{array}{l}\text { Rolling Regression Measure of } \\
\mathrm{V}\end{array}$ & & $-1.62(1.66)^{* *}$ \\
\hline Dummy 1 & $0.08(2.49)^{*}$ & $-0.05(2.69)^{*}$ \\
\hline Dummy 2 & $0.08(1.90)^{* *}$ & $-0.07(2.48)^{*}$ \\
\hline Adjusted R-squared & 0.44 & 0.46 \\
\hline F-statistic & $7.95(0.00)$ & $6.79(0.00)$ \\
\hline B-G Serial Correlation (F Test) & $1.55(0.20)$ & $2.11(0.09)$ \\
\hline $\mathrm{ARCH}(\mathrm{F}$ test $)$ & $1.02(0.40)$ & $1.90(0.12)$ \\
\hline
\end{tabular}

Notes: The figures in parentheses are the absolute t-statistics. * and $* *$ denote significance at the 5 per cent and 10 per cent levels, respectively. F statistics are followed by marginal significance levels in parentheses. The standard errors in model 2 have been adjusted according to the Newy-West procedure due to the finding of serially correlated residuals.

negative and significant for Belgium, Denmark, and Germany ${ }^{8}$. Third, in the rest of the countries, the coefficients of both dummies are insignificant. Therefore, in accordance with our earlier discussion, we can conclude that the creation of the ERM has led to a change in intra-EU exports in four countries only through the following channels: First, through its impact on the anticipation about further real 
Table 5. Error-Correction Regression Results - IRELAND

Dependent Variable: $\Delta \ln \mathrm{X}$

\begin{tabular}{lccc}
\hline & Model 1 & Model 2 & Model 3 \\
\hline Error Correction Term (-1) & $0.03(2.75)^{*}$ & $0.01(1.03)$ & $0.02(1.83)^{* *}$ \\
$\Delta \ln \mathrm{X}(-1)$ & $-0.34(3.40)^{*}$ & $-0.22(2.04)^{*}$ & $-0.21(1.93)^{* *}$ \\
$\Delta \ln \mathrm{X}(-3)$ & & & $-0.11(0.96)$ \\
$\Delta \ln \mathrm{X}(-4)$ & $0.39(4.39)^{*}$ & $0.35(3.39)^{*}$ & $0.32(2.89)^{*}$ \\
$\Delta \ln \mathrm{X}(-5)$ & & $-0.15(1.44)$ & $-0.13(1.23)$ \\
$\Delta \ln \mathrm{Y}(-1)$ & $0.85(2.15)^{*}$ & & $0.57(1.31)$ \\
$\Delta \ln \mathrm{Y}(-2)$ & $0.77(1.72)^{* *}$ & $0.81(1.71)^{* *}$ & $0.51(1.15)$ \\
$\Delta \ln \mathrm{Y}(-3)$ & & & $0.48(1.14)$ \\
$\Delta \ln \mathrm{Y}(-4)$ & & & $0.34(0.80)$ \\
$\Delta \ln \mathrm{P}(-2)$ & $-1.06(3.76)^{*}$ & $-1.12(3.58)^{*}$ & $-0.80(2.66)^{*}$ \\
$\Delta \ln \mathrm{P}(-3)$ & $0.36(1.28)$ & & \\
$\Delta \ln \mathrm{P}(-5)$ & $0.30(1.21)$ & $0.37(1.34)$ & $0.33(1.14)$
\end{tabular}

Moving Standard Deviation Measure of Vol.
$\Delta \mathrm{V}(-1)$
$-5.17(2.29)^{*}$
$\Delta \mathrm{V}(-4)$
$5.02(2.24)^{*}$

$\Delta \mathrm{V}(-5)$

Rolling Regression Measure of Vol.

$\Delta \mathrm{V}(-2)$

$-1.98(1.23)$

$\Delta \mathrm{V}(-3)$

$1.82(1.15)$

GARCH Measure of Volatility

$\mathrm{V}(-3)$

$1.02(0.20)$

Dummy 1

$0.08(2.99)^{*}$

$0.05(1.40)$

$0.08(1.99)^{*}$

Dummy 2

$0.10(2.81)^{*}$

$0.08(1.53)$

$0.12(2.17)^{*}$

Adjusted R-squared

0.47

0.36

0.33

F-statistic

$7.38(0.00)$

$5.74(0.00)$

$4.31(0.11)$

B-G Serial Correlation (F Test)

$0.50(0.73)$

$1.19(0.32)$

$1.69(0.16)$

$\mathrm{ARCH}$ (F test)

$0.89(0.47)$

$0.97(0.43)$

$0.60(0.66)$

Notes: The figures in parentheses are the absolute t-statistics. $*$ and $* *$ denote significance at the 5 per cent and 10 per cent levels, respectively. F statistics are followed by marginal significance levels in parentheses.

integration which would attract more inward FDI and hence contribute to more intra-EU exports. Second, through its impact on the anticipation about restrictive monetary (in particular during the 1980s) and fiscal policies (mostly in the 1990s) which would keep away inward FDI and hence contribute to less intra-EU exports. The negative coefficients for Belgium, Denmark, and Germany imply that the expectation of contractionary monetary and fiscal policies must have been strong 
Table 6. Error-Correction Regression Results - ITALY

Dependent Variable: $\Delta \ln X$

\begin{tabular}{lccc}
\hline & Model 1 & Model 2 & Model 3 \\
\hline Error Correction Term (-1) & $0.01(0.63)$ & & \\
$\Delta \ln \mathrm{X}(-1)$ & $-0.46(4.63)^{*}$ & $-0.43(4.41)^{*}$ & $-0.41(4.24)^{*}$ \\
$\Delta \ln \mathrm{X}(-2)$ & & & \\
$\Delta \ln \mathrm{X}(-3)$ & $0.23(2.35)^{*}$ & & $0.24(2.55)^{*}$ \\
$\Delta \ln \mathrm{X}(-4)$ & & & \\
$\Delta \ln \mathrm{X}(-5)$ & $1.92(1.55)$ & $1.27(1.17)$ & \\
$\Delta \ln \mathrm{Y}(-1)$ & $2.19(1.73)^{* *}$ & & $0.92(0.97)$ \\
$\Delta \ln \mathrm{Y}(-2)$ & & & \\
$\Delta \ln \mathrm{Y}(-3)$ & & $1.07(2.04)^{*}$ & $0.67(1.32)$ \\
$\Delta \ln \mathrm{P}(-1)$ & & & \\
$\Delta \ln \mathrm{P}(-2)$ & $-0.51(0.95)$ & & $-0.57(1.13)$ \\
$\Delta \ln \mathrm{P}(-3)$ & & &
\end{tabular}

Moving Standard Deviation Measure of Vol.

$\Delta \mathrm{V}(-1)$

$\Delta \mathrm{V}(-2)$

Rolling Regression Measure of Vol.

$\Delta \mathrm{V}(-1)$

GARCH Measure of Volatility

$\mathrm{V}$

$0.20(0.01)$

Dummy 1

$0.02(0.35) \quad-0.01(0.52) \quad-0.00(0.23)$

Adjusted R-squared

$0.27 \quad 0.23$

0.25

F-statistic

$\begin{array}{lll}5.33(0.00) & 7.22(0.00) & 6.02(0.00)\end{array}$

B-G Serial Correlation (F Test)

$0.09(0.99) \quad 1.25(0.30) \quad 0.03(1.00)$

$\mathrm{ARCH}$ ( $\mathrm{F}$ test)

$0.31(0.87) \quad 0.17(0.95) \quad 0.39(0.82)$

Notes: The figures in parentheses are the absolute t-statistics. * and $* *$ denote significance at the 5 per cent and 10 per cent levels, respectively. F statistics are followed by marginal significance levels in parentheses.

enough to offset the positive effects of inward FDI in the EU on intra-EU exports and hence lead to an overall negative effect on the supply of these exports.

For Ireland the ERM represented a large change in exchange rate policy as in March 1979 Ireland broke the one-to-one link with Sterling. Despite the reduction in the share of Irish exports to the UK in total Irish exports, there has been a large increase in Irish exports to the continent. According to our interpretation, for Ireland, MNCs, anticipating the increasing degree of integration in the EU goods and factor markets signalled by the monetary integration process that was initiated by the launch of the EMS, increased their investment in real capital (and hence the 
Table 7. Error-Correction Regression Results - THE NETHERLANDS

Dependent Variable: $\Delta \ln \mathrm{X}$

\begin{tabular}{|c|c|c|}
\hline & Model 1 & Model 2 \\
\hline Error Correction Term (-1) & $-0.04(1.89)^{* *}$ & $-0.01(0.44)$ \\
\hline$\Delta \ln X(-1)$ & $-0.21(2.02)^{*}$ & $-0.17(1.75)^{* *}$ \\
\hline$\Delta \ln X(-2)$ & $-0.38(3.63)^{*}$ & $-0.34(3.22)$ \\
\hline$\Delta \ln X(-3)$ & $-0.10(0.96)$ & \\
\hline$\Delta \ln X(-4)$ & $0.25(2.49)^{*}$ & $0.33(3.12)^{*}$ \\
\hline$\Delta \ln Y(-1)$ & & $1.32(1.30)$ \\
\hline$\Delta \ln Y(-2)$ & $1.55(1.51)$ & $1.93(1.98)^{*}$ \\
\hline \multicolumn{3}{|l|}{$\Delta \ln Y(-3)$} \\
\hline$\Delta \ln Y(-4)$ & $1.84(1.94)^{*}$ & $1.66(1.72)^{* *}$ \\
\hline$\Delta \ln \mathrm{P}(-4)$ & $-0.83(1.26)$ & $-0.96(1.51)$ \\
\hline \multicolumn{3}{|c|}{ Moving Standard Deviation Measure of Vol. } \\
\hline$\Delta \mathrm{V}(-3)$ & $-5.46(1.26)$ & \\
\hline$\Delta \mathrm{V}(-4)$ & $9.21(2.18)^{*}$ & \\
\hline \multicolumn{3}{|c|}{ Rolling Regression Measure of Vol. } \\
\hline $\mathrm{V}(-1)$ & & $2.93(1.40)$ \\
\hline $\mathrm{V}(-5)$ & & $-1.88(0.90)$ \\
\hline Dummy 1 & $0.011(0.70)$ & $0.004(0.11)$ \\
\hline Dummy 2 & $-0.001(0.04)$ & $0.013(0.26)$ \\
\hline Adjusted R-squared & 0.35 & 0.27 \\
\hline F-statistic & $4.88(0.00)$ & $3.70(0.00)$ \\
\hline B-G Serial Correlation (F Test) & $0.54(0.71)$ & $0.15(0.96)$ \\
\hline $\mathrm{ARCH}(\mathrm{F}$ test $)$ & $0.80(0.53)$ & $0.94(0.44)$ \\
\hline
\end{tabular}

Notes: The figures in parentheses are the absolute t-statistics. * and $* *$ denote significance at the 5 per cent and 10 per cent levels, respectively. F statistics are followed by marginal significance levels in parentheses.

supply of exports to the rest of the EU). This happened despite the prospects of an income slowdown in the EU from the anticipation of contractionary monetary (dummies $\mathrm{D}_{1}$ and $\mathrm{D}_{2}$ ) and fiscal (dummy $\mathrm{D}_{2}$ ) policies.

The lack of an ERM effect for Italy, according to our results, could be due to the on/off approach to the ERM, as the country left the system for more than four years in the 1990s. The same explanation applies for the UK that was not part of the system for most of our sample period. Our finding of a lack of association between the EMS and the volume of intra-EU exports in some countries is also consistent with the literature that has supplied a number of possible explanations for this, a priori, puzzling result (De Grauwe, 1996). They include, the restrictive fiscal policies followed by the major EMS countries, the supply side problems of 
Table 8. Error-Correction Regression Results - UK

Dependent Variable: $\Delta \ln \mathrm{X}$

\begin{tabular}{|c|c|c|}
\hline & Model 1 & Model 2 \\
\hline Error Correction Term (-1) & $-0.29(5.08)^{*}$ & \\
\hline$\Delta \ln \mathrm{X}(-1)$ & & $-0.21(2.32)^{*}$ \\
\hline \multicolumn{3}{|l|}{$\Delta \ln X(-2)$} \\
\hline \multicolumn{3}{|l|}{$\Delta \ln X(-3)$} \\
\hline$\Delta \ln X(-4)$ & $0.58(6.97)^{*}$ & $0.56(5.88)^{*}$ \\
\hline \multicolumn{3}{|l|}{$\Delta \ln X(-5)$} \\
\hline$\Delta \ln Y(-1)$ & $-1.26(1.94)^{* *}$ & \\
\hline$\Delta \ln Y(-2)$ & $0.87(1.40)$ & $1.44(2.38)^{*}$ \\
\hline$\Delta \ln Y(-3)$ & & $0.64(1.03)$ \\
\hline$\Delta \ln Y(-4)$ & $-1.39(2.49)^{*}$ & $-1.04(1.63)^{* *}$ \\
\hline \multicolumn{3}{|l|}{$\Delta \ln Y(-5)$} \\
\hline$\Delta \ln \mathrm{P}(-1)$ & $0.45(2.03)^{*}$ & \\
\hline$\Delta \ln \mathrm{P}(-2)$ & $0.28(1.26)$ & \\
\hline$\Delta \ln \mathrm{P}(-3)$ & & $-0.46(1.97)^{*}$ \\
\hline$\Delta \ln \mathrm{P}(-4)$ & & $-0.30(1.29)$ \\
\hline \multicolumn{3}{|l|}{$\Delta \ln P(-5)$} \\
\hline Moving Standard Deviation Me & & \\
\hline V & $-0.56(2.05)^{*}$ & \\
\hline \multicolumn{3}{|c|}{ Rolling Regression Measure of Vol. } \\
\hline $\mathrm{V}$ & & $0.12(0.45)$ \\
\hline Dummy 1 & $-0.01(0.19)$ & $-0.02(0.63)$ \\
\hline Adjusted R-squared & 0.49 & 0.40 \\
\hline F-statistic & $11.25(0.00)$ & $8.38(0.00)$ \\
\hline B-G Serial Correlation (F Test) & $1.17(0.33)$ & $1.43(0.23)$ \\
\hline $\mathrm{ARCH}(\mathrm{F}$ test $)$ & $0.11(0.98)$ & $1.46(0.22)$ \\
\hline
\end{tabular}

Notes: The figures in parentheses are the absolute t-statistics. ${ }^{*}$ and ${ }^{* *}$ denote significance at the 5 per cent and 10 per cent levels, respectively. F statistics are followed by marginal significance levels in parentheses.

many European countries, and the slow-down in the trade integration process within the EU since the 1960s.

There has been a scarcity of evidence on the impact of the EMS on intra-EU trade. Exceptions are the studies by Fountas and Aristotelous (1999) and Aristotelous and Fountas (2000) which focus on EMS' impact on intra-EU trade only in the four largest EU-member countries, in a multilateral and bilateral context, respectively. This lack of evidence makes comparison of most of our present results with other studies impossible. Aristotelous and Fountas (2000) find that the EMS boosted Germany's bilateral exports to Italy but reduced those to 
France. This contrasts with the lack of evidence for an EMS impact on Germany's multilateral exports to the other three largest EU countries reported in Fountas and Aristotelous (1999). Our present evidence on multilateral exports in an eightcountry context supports a reduction of Germany's exports to the rest of the EU-8.

\section{Summary and Conclusions}

This paper primarily investigated the impact of the creation of the ERM associated with the launch of the EMS in March 1979 on the volume of intra-EU exports using the techniques of multivariate cointegration and error-correction models to estimate long-run and short-run export functions, respectively. Exports were considered to be a function of foreign income, relative prices, and exchange rate uncertainty. The models were estimated using quarterly data for eight EUmember countries, namely, Belgium, Denmark, France, Germany, Ireland, Italy, the Netherlands, and the UK for the sample period 1973.I-1996.IV. Our empirical approach only allowed us to determine the effects on exports that arise from the anticipation of additional real integration and restrictive macroeconomic policies (as captured by the EMS) on the behaviour of MNCs and their export strategies. The empirical results support a number of conclusions.

Our major conclusion is that the effect of the EMS on intra-EU exports differs across the eight countries included in this study. In Belgium, Denmark, and Germany, the EMS had a negative and statistically significant effect on intra-EU exports, whereas for Ireland the effect was positive. Finally, no effect was found for France, Italy, the Netherlands, and the UK. According to our interpretation, for Ireland, the creation of the anticipation of more EU real integration that originated from the initiation of the monetary integration process (the EMS) must have been very strong to attract MNCs in the country and enhance the export capability of the country. This must have happened despite the prospects for a slowdown in the EU arising from restrictive macroeconomic policies.

The negative effects of the EMS on intra-EU exports for Belgium, Denmark, and Germany imply that the expectation of contractionary national monetary and fiscal policies must have been strong enough to offset the positive effects of inward FDI in the EU on intra-EU exports and hence lead to an overall negative effect on the supply of these exports.

In light of the above discussion, it can be argued that the empirical results of our study provide evidence that suggests that the ERM influenced the volume of intra- 
EU trade, at least for some EU countries. Put differently, there is evidence that a genuine change in a country's exchange rate regime is an important determinant of its volume of exports.

\section{Acknowledgements}

We thank an anonymous referee for helpful comments and suggestions. We also thank participants of the 2003 International Atlantic Economic Society conference in Vienna for their comments. The usual disclaimer applies.

Received 8 March 2004, Accepted 21 February 2005

\section{References}

Aristotelous, K. and S. Fountas, 1996, An empirical analysis of inward foreign direct investment flows in the EU with emphasis on the market enlargement hypothesis, Journal of Common Market Studies 34, 571-583.

Aristotelous, K. and S. Fountas, 2000, The Impact of the Exchange Rate Regime on Exports: Evidence from bilateral exports in the European Monetary System, Journal of Economic_Integration 15, 506-526.

Arize, A.C., 1995, The Effects of Exchange Rate Volatility on U.S. Exports: An Empirical Investigation, Southern Economic Journal 62, 34-43.

Asseery, A. and D.A. Peel, 1991, The Effects of Exchange Rate Volatility on ExportsSome New Estimates, Economics Letters 37, 173-177.

Bini-Smaghi, L., 1991, Exchange Rate Variability and Trade: Why Is It So Difficult to Find any Empirical Relationship?, Applied Economics 23, 927-935.

Brada J. and J. Mendez, 1988, Exchange rate risk, exchange rate regime and the volume of international trade, Kyklos 41, 263-280.

Chowdhury, A.R., 1993, Does Exchange Rate Volatility Depress Trade Flows? Evidence from Error-Correction Models, The Review of Economics and Statistics 75, 700-706.

Cote, A., 1994, Exchange Rate Volatility and Trade, Bank of Canada Working Paper 5.

De Grauwe, P., 1987, International Trade and Economic Growth in the European Monetary System, European Economic Review 31, 389-398.

De Grauwe, P., 1988, Exchange Rate Variability and the Slowdown in Growth of International Trade, IMF Staff Papers 35, 63-84.

De Grauwe, P., 1996, International Money (Oxford University Press, Oxford).

De Grauwe, P., 2000, Economics of Monetary Union (Oxford University Press, Oxford).

De Nardis, S. and C. Vicarelli, 2003, Currency unions and trade: the special case of EMU, Weltwirtschaftliches Archiv, 625-649.

Enders, W. 1995, Applied Econometric Times Series (Wiley, New York). 
Engle, R., and C. W. J. Granger, 1987, Cointegration and Error-Correction: Representation, Estimation, and Testing, Econometrica 55, 251-276.

Fountas, S. and K. Aristotelous, 1999, Has the European Monetary System Led to More Exports ? Evidence from Four European Union Countries, Economics Letters 62, 357 363.

Franke, G., 1991, Exchange Rate Volatility and International Trading Strategy, Journal of International Money and Finance 10, 292-307.

Frankel, J. and A. Rose, 2002, An estimate of the effect of common currencies on trade and income, The Quarterly Journal of Economics 117(2), 437-466.

Giovannini, A., 1988, Exchange Rates and Traded Goods Prices, Journal of International Economics 24, 45-68.

Glick, R. and A. Rose, 2002, Does a currency union affect trade? The time-series evidence, European Economic Review 46, 1125-1151.

Gonzalo, J., 1994, Five Alternative Methods of Estimating Long-Run Equilibrium Relationships, Journal of Econometrics 60, 203-233.

Gotur, P., 1985, Effects of Exchange Rate Volatility on Trade: Some Further Evidence, IMF Staff Papers 32, 475-512.

Granger, C. W. J. and P. Newbold, 1974, Spurious Regression in Econometrics, Journal of Econometrics 2, 111-120.

Gros, D. and N. Thygesen, 1998, European Monetary Integration, (Longman, Essex).

International Monetary Fund, 1984, Exchange Rate Volatility and World Trade, Occasional Paper No. 28.

Lastrapes, W.D. and F. Koray, 1990, Real Exchange Rate Volatility and US Multilateral Trade Flows, The Journal of Macroeconomics 12, 341-362.

McKenzie, M. D., 1999, The Impact of Exchange Rate Volatility on International Trade Flows, Journal of Economic Surveys 13, 71-106.

Micco, A., Stein, E., Ordonez, G. 2003, The currency union effect on trade: early evidence from EMU, Economic Policy 37, 315-356.

Phillips, P. C. B., 1991, Optimal Inference in Cointegrated Systems, Econometrica 59, 283-306.

Pozo, S., 1992, Conditional Exchange Rate Volatility and the Volume of International Trade: Evidence from the Early 1900s, The Review of Economics and Statistics 74, 325-329.

Rose, A. 2000, One money, one market: the effect of common currencies on trade, Economic Policy 30, 7-46.

Rose, A. 2001, Currency unions and trade: the effect is large, Economic Policy 33, 449-461.

Rose, A. 2004, A meta-analysis of the effect of common currencies on international trade, Unpublished manuscript.

Rose, A. and E. van Wincoop, 2001, National money as a barrier to international trade: the real case for currency union, American Economic Review 91(2), 386-390.

Sereu, P. and C. Vanhulle, 1992, Exchange Rate Volatility, Exposure and the Value of Exporting Firms, Journal of Banking and Finance 16, 155-182. 
Stock, J., 1987, Asymptotic Properties of Least Squares Estimators of Cointegrating Vectors, Econometrica 55, 1035-1056.

Stokman, A. C. J. 1995, Effect of Exchange Rate Risk on Intra-EC Trade, De Economist 143, 41-54.

Thursby, J, and M. Thursby, 1987, Bilateral Trade Flows, the Linder Hypothesis, and Exchange Risk, The Review of Economics and Statistics 69, 488-495.

Viaene, J-M. and C. de Vries, 1992, International Trade and Exchange Rate Volatility, European Economic Review 36, 1311-21. 